Global Conferences Series:

Social Sciences, Education and Humanities (GCSSSEH), Volume 6, 2020

International Conference Fakultas Tarbiyah dan Keguruan Universitas Islam Negeri Imam Bonjol Padang (ICFTKUINIBP) 2020

DOI: https://doi.org/10.32698/icftk415

\title{
Parenting in Overcoming Learning Difficulties in Middle and Late Children "Merdeka Belajar" in Family Education
}

\section{Pengasuhan dalam Mengatasi Kesulitan Belajar Anak Tengah dan Akhir "Merdeka Belajar" dalam Pendidikan Keluarga}

\author{
Fauza Masyhudia ${ }^{a}$, Rendy Nugraha Frasandy ${ }^{a}$, Yumna $^{b}$ \\ ${ }^{a}$ Universitas Islam Negeri Imam Bonjol, Padang, Indonesia, ${ }^{b}$ Sekolah Tinggi Agama Islam, Solok, Indonesia \\ E-mail: fauzamasyhudi@uinib.ac.id
}

\begin{abstract}
The current independence for learning tends to be aimed at school education. Nevertheless, the family as the first and foremost educational institution cannot be ignored to cooperate with schools by presenting an independent and fun learning atmosphere. The focus of this research is parenting in overcoming learning difficulties of middle and late children based on "merdeka belajar". This study aims to analyze the parenting based on "merdeka belajar". This study used a qualitative research method with a multiple case research approach. The forms of independent learning that are carried out in overcoming learning difficulties of middle and late children are 1) giving attention to children; 3) sacrifice more time to guide children; 3 ) The open attitude of parents to correct mistakes if any; 4) Give advice; 5) Provide more experiences to children; 6) Facilitating children with activities according to their interests; 7) Facilitating children by attending non-formal educational institutions such as courses if needed.
\end{abstract}

Keywords: Parenting, learning difficulties, merdeka belajar

\section{PENDAHULUAN}

Pendidikan memiliki peran yang sangat penting dalam kehidupan. Tanpa pendidikan, seseorang tidak akan bisa mempertahankan kelangsungan hidupnya. Melalui pendidikan, seseorang tentu akan menuju pada capaiannya. Keluaran (out put) dari pendidikan sangat berkaitan dengan tujuan yang ditetapkan.Namun untuk mencapai tujuan tersebut tentu saja tidak semudah membalik telapak tangan. Akan tetapi, untuk mencapai hasil yang diinginkan, pendidikan membutuhkan proses yang panjang, bertahap dan berkelanjutan .

Proses pendidikan dilaksanakan dalam lembaga-lembaga pendidikan. Dalam kajian ilmu pendidikan, terdapat beberapa lembaga pendidikan sebagai wadah tempat berlangsungnya pendidikan. Pertama, lembaga pendidikan formal yang merupakan lembaga yang terstruktur dan memiliki aturan yang jelas. Selanjutnya, lembaga pendidikan non formal seperti lembaga pelatihan, kelompok belajar, majelis taklim dan sebagainya. Sedangkan lembaga pendidikan informal merupakan lembaga pendidikan rumah tanggaatau keluarga yang tak kalah besar pengaruhnya dalam pembentukan kepribadian anak. (Ramayulis, 2002)

Keluarga merupakan tempat berlangsungnya pendidikan yang pertama dan utama bagi anak. (Daradjat, 1994) Keluarga merupakan elemen terkecil dari masyarakat yang memiliki peran yang sangat urgen dalam pembentukan pribadi anak.Sehingga peran keluarga ini tidak dapat dipandang sebelah mata dalam membentuk anak menjadi pribadi yang berilmu dan beretika.Keluarga sebagai wadah pendidikan yang pertama bagi anak dapat dipahami melalui interaksi yang dilalui anak pada masa awal kehidupannya adalah lingkungan keluarga. Dalam lingkungan sosial keluarga inilah, anak terlibat dalam interaksi bersama orang tuanya. Sementara terma pendidikan utama yang disandangkan pada keluarga dapat dipahami dengan sangat kuatnya pengaruh pendidikan yang diberikan pada anak dalam keluarga. Pengalaman-pengalaman yang

Copyright (C2020, the Authors. Published by Redwhite Press.

Page | 146

This is an open access article under the CC BY-NC license

(http://creativecommons.org/licenses/by-nc/4.0). 
diperoleh anak dalam keluarga dapat dikatakan sebagai pondasi yang akan mempengaruhi perkembangan perilaku anak selanjutnya.

Apabila dilihat perkembangan masyarakat modern saat ini, keluarga memegang peranan yang menentukan eksistensi dan perkembangan suatu masyarakat. Menurut Saptono, keluarga-keluarga yang menjadi harapan dalam kehidupan bangsa yang multireligi dan multibudaya pada hari ini adalah keluarga yang beriman yang mampu mengungkapkan kasih yang tulus secara nyata terhadap sesama dan keluarga modern yang sanggup menahan badai gerak zaman bukan dengan prasarana yang serba mewah dan canggih, melainkan dengan "wawasan keluarga modern, yaitu: kesetaraan, saling menghormati, otonomi, pengambilan keputusan melalui komunikasi dan bebas dari kekerasan." Selanjutnya, menurutnya, yang paling penting ialah keluarga Indonesia mesti berusaha keras untuk menumbuhkembangkan karakter yang baik (good character) dalam diri anak, karena keluarga memiliki efek yang paling intens terhadap anak selama masa tumbuh kembang mereka(Saptono, 2011).

Pendidikan merupakan sebuah sistem.Menurut kamus Besar Bahasa Indonesia, sistem merupakan perangkat unsur yang membentuk suatu totalitas karena saling berkaitan secara teratur.Ia juga berarti metode dan susunan teratur dari asas, teori, pandangan dan sebagainya. (Departemen Pendidikan Nasional, 2008).Menurut Muhammad Qutb, sistem pendidikan memiliki keterpaduan yang lengkap, keserasian, realisme yang idealis serta bersifat positif (Quthb, 1993). Sistem terdiri dari komponen - komponen yang saling bekerja sama dan berkaitan satu sama lain untuk mencapai tujuan. Demikian juga halnya dalam pendidikan dalam keluarga.Pendidikan dalam keluarga merupakan suatu sistem.Tujuan itu sendiri merupakan salah satu komponen yang berada dalam sistem pendidikan Islam. Sementara terdapat beberapa elemen lain yang terkait dengan tujuan pendidikan dan juga mengacu pada pencapaian tujuan tersebut, yakni pendidik, peserta didik, metode, materi dan sebagainya yang saling bekerja sama untuk mencapai tujuan pendidikan Islam.

Menyadari pendidikan keluarga sebagai pendidikan yang pertama dan utama dalam kehidupan seseorang anak manusia, berkoherensi dengan tujuannya, serta dengan keterkaitan antar komponenkomponennya dalam mencapai tujuan tersebut, maka dibutuhkan belajar yang bahagia, menyenangkan, nyaman, yang saat ini diistilahkan dengan merdeka belajar. Merdeka belajar menginginkan adanya kemerdekaan dan keleluasaan dalam mengekplorasi potensi peserta didiknya secara maksimal dengan menyesuaikan minat, bakat serta kecendrungan masing-masing peserta didik (Mustaghfiroh, 2020). Merdeka belajar merupakan salah satu bentuk penerapan nilai-nilai dalam membangun karakter bangsa dimulai yang dari pembenahan sistem pendidikan dan metode belajar. Tujuan dari merdeka belajar, yakni menciptakan pendidikan yang menyenangkan yang selama ini lebih menekankan pada aspek pengetahuan daripada aspek keterampilan (Ainia, 2020).

Faktor utama yang mendukung keberhasilan program merdeka belajar adalah adanyakerja sama yang bersinergiantara sekolah dengan keluarga dalam membantusiswadalam mengatasi kesulitan belajar, memperbaiki perilaku dan kebiasaan buruk, serta memberikan penguatan pada ranah intelektual dan spiritual. Di samping itu juga untuk menghasilkansumber daya manusia yang cerdas, cakap mandiri, , kreatif dan inovatif, sehingga dapat bertahan dalam menghadapi berbagaitantangan dan permasalahan dimasa depan.(Wahdani and Burhanuddin, 2020).

Penelitian berhubungan dengan merdeka belajar sudah mulai menjamur.Sementara merdeka belajar dalam pendidikan keluarga sangat jarang ditemukan.Firda Wahdani dan Burhanuddin menulis tentang Pendidikan Keluarga di Era Merdeka. Hasil penelitian menunjukkan bahwa dengan penerapan "merdeka belajar" dalam lingkungan keluarga, maka siswa akan terbantu dalam memecahkan kesulitan belajar, memperbaiki perilaku dan kebiasaan buruk, serta memberikan penguatan pada ranah intelektual dan spiritual. Diharapkan pendidikan Indonesia lebih maju dan berkualitas, melahirkan generasi yang mampu menghadapi berbagaitantangan di masa mendatang. (Wahdani and Burhanuddin, 2020).

Sementara itu, pada penelitian ini, peneliti ingin menganalisis merdeka belajar dalam pendidikan keluarga siswa berprestasi, khususnya pada pengasuhan terhadap anak tengah dan remaja mengatasi kesulitan belaja yang berlandaskan pada merdeka belajar.

\section{METODE}

Penelitian ini menggunakan metode kualitatif dengan pendekatan studi kasus.Penelitian ini menggunakan pendekatan studi kasus karena peneliti mengeksplor kedalaman program, proses, aktivitas, peristiwa, satu atau lebih individu. Informasi-informasi detail dikumpulkan menggunakan beragam prosedur pengumpulan data selama periode waktu yang berkelanjutan (Creswell and Creswell 2017). Pada penelitian ini akan dieksplor tentang pengasuhan dalam mengatasi kesulitan belajar anak tengah dan akhir pada 
beberapa keluarga siswa-siswa berprestasi di Padang. Dengan demikian, pendekatan yang cocok digunakan dalam penelitian ini adalah pendekatan studi kasus jenis multiple case research.Metode pengumpulan data adalah wawancara, observasi dan dokumentasi. Teknik pengolahan data adalah Analisis data Miles and Huberman ini dilakukan dengan 4 tahapan langkah: pengumpulan data, reduksi data, penyajian data dan penarikan kesimpulan (Miles and Huberman 1994)

\section{HASIL DAN PEMBAHASAN \\ Hasil Penelitian}

X1, salah seorang siswa berprestasi, ketika masa kecilnya di Indonesia, mengalami persoalan komunikasi. X1 masih mengalami kesulitan berkomunikasi bahasa daerah (minang) ketika kelas 3 SD, namun ia telah bisa memahami isi pembicaraan yang berbahasa daerah tersebut. Ketika duduk di kelas 4 SD, X1 mulai bisa berkomunikasi dengan bahasa Minang. Akan tetapi kendala komunikasi yang dihadapinya tersebut ternyata tidak menghambat dirinya untuk tetap berprestasi. Ibu X1 menjelaskan bahwa awalnya X1 menceritakan kepada Ibu X1 bahawa ia tidak dipahaminya pelajaran di sekolah dan nilai yang diperolehnya ketika awal memasuki sekolah sering tidak memenuhi standar kelulusan, bahkan jauh dari standar tersebut; berkisar 0 (nol) sampai 3 (tiga).Maka sejak saat itu, Ibu X1 selalu menanyakan kepada anaknya tentang pelajaran yang tidak dipahaminya setiap pulang sekolah.Setelah itu, Ibu X1 menerangkan kembali pelajaran tersebut. Alhasil, ketika duduk di bangku SD, X1 selalu meraih peringkat 1 di kelas sejak kelas 1 sampai dengan kelas 6.

Kendala dalam komunikasi ini juga dialami oleh X2. X2 yang semula bersekolah di Surabaya, pada kelas 3 SD, ia dan keluarga pindah ke Padang. Ketika awal mengikuti pendidikan di Padang, prestasinya menurun. Padahal ketika sekolah di Surabaya, ia meraih juara kelas. Ternyata setelah ditanyakan kepadanya, ia tidak memahami bahasa yang digunakan guru dalam pembelajaran yakni bahasa daerah (minang). Setelah mengetahui persoalan tersebut, guru menggunakan bahasa Indonesia dalam pembelajaran. X2 kembali meraih peringkat 1 sebagaimana yang pernah diraihnya ketika sekolah di Surabaya sebelumnya.

Berikutnya dalam belajar membaca Al-Quran, X1 juga mengalami persoalan komunikasi. Ketika X1 duduk di kelas 1 SD dan mulai belajar mengaji di mesjid, X1 sering dimarahi karna tidak bisa mengaji.Untuk persoalan ini, Bapak X1 meluangkan lebih banyak waktunya untuk mengajari X1 sampai mampu membaca Al-Quran.

Selanjutnya, Ibu X2 menjelaskan bahwa ia sering memeriksa tas anak-anaknya di malam hari, termasuk tas X2. Ibu X2 mengoreksi buku kerjaan anaknya di sekolah. Lalu membahasnya dengan anak ketika ada waktu senggang, misalnya sambil nyantai, sambil menonton, dan sebagainya.Jika X2 telah selesai mengerjakan PR, Ibu X2 menanyakan kepada putrinya apakah PR-nya perlu diperiksa atautidak. Adakalanya $\mathrm{X} 2$ yakin dengan apa yang telahdikerjakannya, namun pernah juga X2 yang meminta diperiksakan PR-nya oleh sang ibu.

X3 sempat mengalami kemunduran dalam belajarnya di sekolah.Sampai-sampai gurunya memberitahukan kepada orang tua X3 tentang kemunduran tersebut.Ketika itu, orang tua memang lebih memperhatikan adik X3 yang ketika itu baru lahir.X3 tidak hanya mengalami kemunduran prestasi di sekolah, namun juga di tempat belajar mengajinya.Orang tua X3 sangat bersyukur guru mengajinya juga menelphon dan memberitahukan kemunduran yang dialami X3. Ibu X3 pun minta maaf kepada gurunya bahwa kesalahan adalah pada orang tua yang lalai dan kurang perhatian terhadap X3. Sejak saat itu, Orang tua X3 membuat komitmen untuk berbagi tugas mengasuh anak mereka.Bapak X3 pulang dari kerjanya lebih cepat dari sebelumnya yaitu sebelum magrib.Setelah magrib Bapak X3 mengasuh anak yang bungsu dan Ibu X3 mengasuh Tia. Ibu sangat bersyukur karenaketika menerima raport, anaknya masih bisa mempertahankan juara di sekolah dan tempat mengajinya.Selanjutnya Ibu X3 juga menjelaskan bahwa untuk mengatasi kemunduran prestasi yang pernah dialaminya, X3 suka menulis kata-kata yang mengandung motivasi dan menempelnya di kamarnya.Ibu X3 pernah melihat kata-kata motivasi yang dipajang oleh sang putri di kamarnya "saya harus berhasil dengan nilai 100."

Ibu X3 menceritakan bahwa X3 sering menyalahkan orang lainketika X3 mengalami kegagalan. Hal ini terlihat sejak Taman Anak-anak (TK). Ketika TK, jika kalah dalam perlombaan, ia mengambil posisi dekat piala karena ingin memiliki piala tersebut. Sikapnya yang belum bisa menerima kekalahan ini berlangsung lama, termasuk sampai usia anak-anak tengah dan akhir ini, X3 pun belum juga bisa menerima kekalahannya jika kalah dalam perlombaan. Ibu X3 sering menjelaskan bahwa terkadang ada orang yang lebih pintar dari kita. 
Ibu X3 memandang bahwa sikap menerima kekalahan juga dapat dipupuk lantaran sudah sering mengikuti perlombaan dan juga pernah mengalami kegagalan. Di samping itu Ibu X3 juga memandang bahwa memasukkkan X3 pada sanggar menari salah satunya ialah untuk menghilangkan ego X3.

Bapak X3 dan Ibu X3 pernah mengajarkan X3 mata pelajaran yang diujikan pada UN berdasarkan soal yang diberikan oleh sekolah.Ketika itu, ada soal-soal yang mana X3 belum mengetahui jawabannya dan belum belajar tentang hal tersebut, maka ayah dan ibu turut membantunya untuk memahami soal tersebut. Ketika pra UN, X3 rangking 40 an, ujian UN dapat rangking 2. Adapun kiat orang tua untuk membangkitkan kembali semangatnya adalah dengan selalu mengajaknya berbincang dari hati ke hati.Ibu X3 sampai menangis dalam memberikan nasehat kepadanya.Ibu X3 sering menjelaskan kepada anaknya tentang pengorbanannya mengantar jemput anaknya. Ibu X3 juga menjelaskan tentang kasih sayangnya kepada anaknya bahwa ia bolak balik mengantarkan anaknya. Ia menjelaskan bahwa ia mengantarkan anaknya dari Balai Baru ke sekolahnya di Marapalam. Dari tempat kerja di Gunung Pangilun, Ibu X3 menjemput anaknya ke Marapalam untuk diantarkan les ke Lubuk begalung.Kemudian Ibu X3 singgah ke Parak Karakah menjemput adiknya yang dititip di rumah neneknya.Setelah itu langsung ke Balai Baru.Seperti itu terus sampai X3 tamat SD. Selanjutnya Ibu X3 menyentuh hati sang anak dengan ungkapannya bahwa jangan sampai air mata Ibu X3 menetes dikarenakan perilaku yang tidak baik dan sifat malas sang anak. Jika sempat air mata orang tua menetes, maka anak tersebut berdosa, durhaka kepada orang tua. Ibu X3 juga menjelaskan bahwa persoalan biaya pendidikan dan lain-lain untuk anaknya tidak perlu dipikirkan oleh sang anak, cukup ia dan suaminya yang akan mengusahakannya.

Sementara itu, X4 yang selalu memperoleh juara I di kelasnya sejak kelas I sampai dengan kelas 4 sempat mengalami penurunan prestasi. Ketika kelas 5, X4 meraih juara 2. Orang tua X4 merasa perlu mengetahui dimana kekurangan anaknya.Ibu X4 juga menasehati agar belajar lebih rajin. Kemudian Ibu X4 memasukkan X4 les ketika kelas 6. Kebetulan wali kelas membuka les. Ketika semester akhir kelas 6, X4 kembali meraih juara I dan memperoleh nilai tertinggi UN di sekolahnya.

\section{Pembahasan}

Pengasuhan merupakan pemeliharaan anak terhadap biaya pendidikan dan dari segala yang membahayakan dirinya karena ia belum mampu berdiri. Pengasuhan merupakan melakukan pemeliharaan anak-anak yang masih kecil atau yang sudah besar tetapi belum mumayyiz, tanpa perintah daripadanya, menyediakan sesuatu untuk kebaikan anak, menjaganya dari sesuatu yang merusak jasmani, rohani dan akalnya agar mampu berdiri sendiri dalam menghadapi kehidupan dan mampu memikul tanggung jawab jika sudah dewasa." (Manan, 2016).Dengan demikian, maka pengasuhan hendaknya dilakukan dengan penuh kehangatan dan kenyamanan.

Keluarga hendaknya bisa memberikan rasa hangat dan nyaman bagi para anggotanya.(LN, 2016).Rumah dapat ditata dengan baik dan rapi, lingkungan dibenahi, disertai dengan hubungan yang hangat dan bersenda gurau antar anggota keluarga.Suasana yang bersih, rapi otomatis memicu anak agar mampu menjaga keteraturan dan kebersihan ruangan, menempatkan sesuatu pada tempatnya.Hal ini dapat terwujud dengan adanya keteladanan, latihan dan pembiasaan yang diberikan oleh orang tua terhadap anaknya.

Amirulloh Syarbini menjelaskan bahwa keluarga hendaknya bisa berfungsi rekreatif dengan adanya suasana tenang, damai, jauh dari ketegangan(Syarbini, 2014).Dengan demikian fungsi rekreatif dalam keluarga dapat terwujud jika ada perasaan nyaman, betah dan tidak merasa asing di rumah.Suasana di rumah pun memberikan ketentraman dan dapat mengembalikan tenaga yang telah terkuras karena kesibukan seharihari.

Keluarga juga hendaknya dapat menjadi pelindung bagi para anggota keluarganya dari segala yang menimbulkan ketidaknyamanan (fisik-psikologis) para anggotanya.Adapun Amirulloh Syarbini memandang bahwa perlindungan pada fungsi keluarga ini ditujukan pada 3 (tiga) hal yaitu "fisik, mental dan moral".Menurutnya, inti dari fungsi proteksi keluarga ialah keluarga mampu melindungi anggotanya baik dari segi fisik, mental maupun moral para anggotanya dari hal-hal yang membahayakan mereka di dunia dan di akhirat.(Syarbini 2014).

Adapun perlindungan secara psikis terlihat pada fungsi keluarga untuk menciptakan ketenangan, ketentraman, kasih sayang. Allah SWT berfirman:

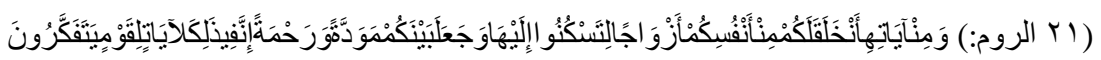

Artinya: "Dan di antara tanda-tanda (kekuasaan)-Nya ialah Dia menciptakan untuk kamu dari jenis kamu sendiri supaya kamu merasa tentram kepadanya, dan dijadikan-Nya di antara kamu mawaddah dan rahmah. Sesungguhnya pada yang demikian itu benar-benar terdapat tanda-tanda bagi kaum yang berpikir.” (Q.S. A-Rum/ 30: 21) 
Dengan demikian, diharapkan kehidupan berkeluarga dapat membawa pada ketentraman, ketenangan dan kedamaian pada jiwa seseorang.Berfungsi atau tidaknya keluarga dapat diamati dengan difasilitasinya suasana yang mendorong kebutuhan-kebutuhan bagi anggota keluarga.Jika keluarga telah dapat melaksanakan fungsinya dengan baik, maka keluarga mampu mewujudkan tujuan keluarga dalam menciptakan generasi yang berkualitas.

Berdasarkan pengertian pengasuhan yang telah dipaparkan sebelumnya, maka pengasuhan meliputi aspek jasmani, rohani dan akal anak. Pada penelitian ini, pengasuhan dibatasi pada mengatasi kesulitan belajar anak, yang jika ditelusuri akan berhubungan dengan aspek rohani dan akal anak. Kesulitan belajar itu sendiri merupakan keadaan yang menyebabkan timbulnya hambatan-hambatan dalam proses belajar. (Hakim)

Pada hasil penelitian yang telah dikemukakan sebelumnya, dapat dipahami bahwa persoalan komunikasi menjadi sangat penting untuk mencapai keberhasilan belajar.Jika seseorang mengalami gangguan dalam komunikasi pembelajaran, ternyata mempengaruhi pemahamannya terhadap materi pelajaran dan berpengaruh tidak baik terhadap prestasi belajar. Komunikasi merupakan proses penyampaian pesan dari sumber kepada penerima pesan agar sampai kepada penerima pesan dan mempengaruhinya (Sanjaya, 2012). Pada hakikatnya komunikasi dibutuhkan dalam proses pembelajaran. Proses pembelajaran melibatkan pendidik sebagai sumber informasi yang akan menyampai pesan/materi kepada penerima pesan yaitu peserta didik. Namun terkadang dalam penyampaian pesan terjadi noise yang merupakan gangguan dalam komunikasi.Dalam hal ini, orang tua berusaha membantu anaknya, dan ternyata mampu mengatasi kesulitan anak dalam belajar. Ibu X1 menjelaskan awalnya anaknya juga cerita di rumah bahwa ia memperoleh nilai yang tidak bagus. Sejak saat itu, Ibu X1 pun juga sering menanyakan kesulitan anaknya memahami pelajaran di sekolah.Dengan demikian keberhasilan X1 tidak terlepas dari perhatian yang diberikan orang tua dengan selalu menanyakan tentang pelajaran anaknya di sekolah.

Dalam kesulitan belajar membaca Al-Quran, Bapak X1 memberikan perhatian pada anaknya.Ketika anaknya mengalami kesulitan, Bapak X1 berada di sampingnya. Ia bahkan meluangkan waktu untuk mengajari anaknya mengaji. Menurut John Santrock, terdapat hubungan antara pengasuhan dengan motivasi anak. Beberapa praktek pengasuhan yang meningkatkan motivasi dan prestasi ialah (1) mengenal betul anak dan memberi tantangan dan dukungan dalam kadar yang tepat (2) memberikan iklim emosional yang positif kepada anak sehingga orang tua dapat menginternalisasikan nilai dan tujuan yang diharapkan oleh orang tua dan (3) memberikan contoh perilaku yang memberi motivasi kepada anak, misalnya, orang tua suka bekerja keras, gigih menghadapi tantangan dan sebagainya.(Santrock 2007).

Ibu X2 yang sering memeriksa tas sekolah anaknya, menurut penulis, adalah bentuk perhatian yang diberikan oleh orang tua kepada anak. Perhatian merupakan hal yang krusial dalam pendidikan dan pengasuhan. Allah SWT berfirman dalam Q.S. Al-Tahrim: 6

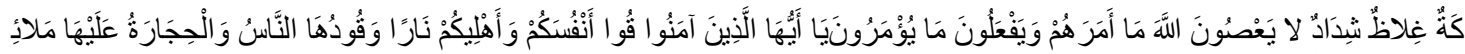

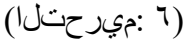

Artinya: "Hai orang-orang yang beriman, peliharalah dirimu dan keluargamu dari api neraka yang bahan bakarnya adalah manusia dan batu; penjaganya malaikat-malaikat yang kasar, yang keras, yang tidak mendurhakai Allah terhadap apa yang diperintahkan-Nya kepada mereka dan selalu mengerjakan apa yang diperintahkan."(Q.S. Al-Tahrim/66: 6)

Bagaimana pendidik akan memelihara keluarganya dari api neraka jika ia tidak memperhatikan, tidak mengawasi mereka. Bagaimana pendidik dalam keluarga akan menyuruh anggota keluarganya mendirikan shalat, jika hal tersebut tidak menjadi perhatian baginya. Bagaimana akan mendidik anak mencintai nabi, keluarga nabi dan membaca al-Quran, jika pendidik juga tidak memperhatikan anaknya. Menurut Nashih 'Ulwan, ajarilah, didiklah akan terlaksana jika pendidik memperhatikan segala gerak-gerik dan tindak tanduk anak. Sehingga jika ada anak yang melalaikan kewajiban, segera diluruskan.Jika anak melihat hal yang mungkar, dicegah supaya tidak didekati. Jika berbuat kebaikan, pendidik bersyukur dan memberikan dorongan agar senantiasa melaksanakan kebaikan.('Ulwan 2012). Nabi muhammad pun juga melakukan hal demikian. Muhammad memberikan teladan yang baik kepada umatnya dalam memperhatikan shahabatnya dengan sebaik-baiknya.Rasul selalu merasa kehilangan jika salah seorang sahabat tidak tampak dan bertanya tentang keadaannya.Rasulullah SAW juga memperhatikan shahabat yang lalai dan mendorong mereka kepada kebaikan.

Orang tua X3 menyadari akan kemuduran yang dialami anaknya dikarenakan kelalaian dan kurangnya perhatian mereka terhadap X3. Terdapat beberapa pelajaran yang dapat dipetik dari pengalaman orang tua X3 ini.Pertama, begitu pentingnya perhatian diberikan kepada anak.Betapapun berprestasinya anak, jika 
perhatian tidak diberikan sebagaimana mestinya, maka prestasi anak bisa menurun.Kedua, jika orang tua melakukan kesalahan dalam mendidik anaknya, maka sikap orang tua yang terbuka, mengakui kesalahannya dan mau memperbaiki kesalahannya sangat diperlukan demi terwujudnya kebaikan bersama. Ketiga, kondisi setiap keluarga berbeda-beda sehingga apapun bentuknya, kerja sama antara ayah dan ibu dalam mendidik anak sangat dibutuhkan.

Hal ini turut menjadi kesulitan bagi Ibu dalam melaksanakn pendidikan dan pengasuhan terhadap anaknya. Menurut Hurlock, sikap menyalahkan orang lain merupakan salah satu bahaya psikologis yang dialami oleh anak pada masa anak-anak akhir. Hal ini terjadi karena anak tidak puas dengan diri sendiri, lalu menggunakan cara pertahanan seperti rasionalisasi untuk menjelaskan kelemahan-kelemahan atau proyeksi untuk menyalahkan orang lain. Hal lain yang juga dilakukan anak pada masa ini ialah menghindar dengan melamun atau berkhayal. Seiring perkembangan usianya, mekanisme ini kehilangan efektifitas dan tidak berguna lagi (Hurlock et al., 1990).Begitu juga yang dialami oleh X3. Beberapa cara yang dilakukan oleh orang tua mengatasi sikap anak ini adalah dengan selalu memberi sang anak nasehat, memperbanyak pengalaman mengikuti perlombaan dan mengembangkan kecerdasan emosional dan sosial anak dengan kegiatan yang sesuai dengan minat anak. Demikianlah cara yang digunakan oleh Ibu X3 untuk menghilangkan sikap tidak mau menerima kekalahan pada diri anaknya. Kesulitan belajar juga dapat diatasi dengan bimbingan dari orang tua.

\section{SIMPULAN}

Hasil pembahasan ini menunjukkan bahwa merdeka belajar juga perlu dilaksanakan dalam keluarga karena keluarga adalah lembaga pendidikan pertama dan utama, keluarga memiliki fungsi di antaranya fungsi pendidikan, rekreatif dan perlindungan, pendidikan keluarga juga merupakan sistem dengan semua komponennya untuk mencapai tujuan dari unit terkecil ini. Pendidikan di mana pun dilaksanakan mesti dilaksanakan dengan bahagia, tanpa tekanan.

Pengasuhan sebagai bagian dari pendidikan keluarga juga dilandasi dengan merdeka belajar. Merdeka belajar dalam pengasuhan yang dilakukan orang tua terhadap anak tengah dan akhir dalam mengatasi kesulitan belajarnya dapat dilakukan dengan 1) memberikan perhatian kepada anak; 2) mengorbankan lebih banyak waktu untuk membimbing anak; 3) Sikap terbuka orang tua memperbaiki kesalahan jika ada; 4) Memberi nasehat; 5) Memberikan pengalaman yang lebih banyak kepada anak; 6) Menfasilitasi anak dengan kegiatan sesuai minatnya; 7) Menfasilitasi anak dengan mengikuti kursus jika dibutuhkan.

\section{REFERENSI}

Ainia, Dela Khoirul. (2020). "Merdeka Belajar Dalam Pandangan Ki Hadjar Dewantara Dan Relevansinya Bagi Pengembanagan Pendidikan Karakter.” Jurnal Filsafat Indonesia 3(3):95-101.

Cresswel, JohnW. Research Design Qualitative, Quantitative and Mixed Method Approach. Los Angeles, London, New Delhi, Singapore, SAGE.

Departemen Pendidikan Nasional, (2008). "Kamus Besar Bahasa Indonesia.” Jakarta: Gramedia Pustaka Utama.

Hakim, Thursan. Belajar Secara Efektif. Niaga Swadaya.

Hurlock, Elizabeth Bergner, Istiwidayanti, Ridwan Max Sijabat, and Soedjarwo. (1990). Psikologi Perkembangan: Suatu Pendekatan Sepanjang Rentang Kehidupan. Erlangga, Jakarta.

Manan, Abdul. (2016). Penerapan Hukum Acara Perdata Di Lingkungan Peradilan Agama Ed. 2. Kencana.

Mathew B. Milles and A. Michael Huberman, An Expanded Sourcebook Qualitative Data Analysis. Thousand Oaks, London, New Delhi, SAGE, 1994, p. 35

Mustaghfiroh, Siti. (2020). "Konsep 'Merdeka Belajar' Perspektif Aliran Progresivisme John Dewey." Jurnal Studi Guru Dan Pembelajaran 3(1):141-47.

N., Syamsu Yusuf L. (2016). Psikologi Perkembangan Anak \& Remaja. Remaja Rosdakarya.

Quthb, Muhammad. (1993). "Sistem Pendidikan Islam, Terjemahan Salman Harun." Bandung: Al Ma" Arif. Ramayulis. (2002). Ilmu Pendidikan Islam. Kalam Mulia.

Sanjaya, Wina. (2012). Media Komunikasi Pembelajaran. Jakarta: Kencana Prenada Media Group.

Santrock, John W. (2007). "Psikologi Pendidikan (Terjemahan)." Tri Wibowo BS Jakarta: Kencana Prenada Media Group. Sudjana.(2005). Metoda Statistika. Bandung: Tarsito.

Saptono. (2011). "Dimensi-Dimensi Pendidikan Karakter, Wawasan, Strategi, Dan Langkah Praktis." Salatiga: Esensi Erlangga Group.

Syarbini, A. (2014). Model Pendidikan Karakter Dalam Keluarga. Elex Media Komputindo. 
'Ulwan, A. N. (2012). Pendidikan Anak Dalam Islam. Penerbit Insan Kamil Solo.

Wahdani, Firda, and Hamam Burhanuddin. (2020). "Pendidikan Keluarga di Era Merdeka Belajar." Al-Aufa: Jurnal Pendidikan dan Kajian Keislaman 2(1):1-10. 